\title{
Author Correction: Relative configuration of micrograms of natural compounds using proton residual chemical shift anisotropy
}

\author{
Nilamoni Nath (D), Juan Carlos Fuentes-Monteverde (D), Dawrin Pech-Puch (D), Jaime Rodríguez (D), \\ Carlos Jiménez (1D, Markus Noll, Alexander Kreiter, Michael Reggelin (1D, \\ Armando Navarro-Vázquez (i) \& Christian Griesinger (D)
}

Correction to: Nature Communications https:/doi.org/10.1038/s41467-020-18093-5, published online 01 September 2020.

The original version of the Supplementary Information associated with this Article contained errors in Supplementary Fig. 9a and on page 7. In both cases, chemical formula of the liquid crystalline medium was drawn incorrectly. The HTML has been updated to include a corrected version of the Supplementary Information; the original incorrect versions of these Figs. can be found as Supplementary Information associated with this Correction.

Published online: 29 September 2020

\section{Additional information}

Supplementary information is available for this paper at https://doi.org/10.1038/s41467-020-18927-2.

\footnotetext{
(c) Open Access This article is licensed under a Creative Commons Attribution 4.0 International License, which permits use, sharing, adaptation, distribution and reproduction in any medium or format, as long as you give appropriate credit to the original author(s) and the source, provide a link to the Creative Commons license, and indicate if changes were made. The images or other third party material in this article are included in the article's Creative Commons license, unless indicated otherwise in a credit line to the material. If material is not included in the article's Creative Commons license and your intended use is not permitted by statutory regulation or exceeds the permitted use, you will need to obtain permission directly from the copyright holder. To view a copy of this license, visit http://creativecommons.org/licenses/by/4.0/.
}

(C) The Author(s) 2020 